\title{
Intramammary infections with different non-aureus staphylococci in dairy cows
}

\author{
A.-K. Nyman, ${ }^{*} \dagger^{1}$ C. Fasth, $\ddagger$ and K. Persson Waller ${ }^{*} \S$ \\ *Department of Animal Health, Växa Sverige, SE-101 24 Stockholm, Sweden \\ †Department of Animal Health and Antimicrobial Strategies, and \\ fDepartment of Microbiology, National Veterinary Institute (SVA), SE-756 89 Uppsala, Sweden \\ §Department of Clinical Sciences, Swedish University of Agricultural Sciences, SE-750 07 Uppsala, Sweden
}

\begin{abstract}
Subclinical mastitis causes an increase in milk somatic cell count (SCC) and can lead to reduced milk production and early culling. In many countries, nonaureus staphylococci (NAS) is the most common bacterial finding in subclinical mastitis of dairy cows. New methodology makes it possible to identify NAS species, but knowledge about the epidemiology is limited. The objective of this project was to improve advisory services for mastitis control by investigating associations between NAS and SCC, milk production, and persistence of intramammary infections (IMI). Farmers who had sent milk samples to the Swedish National Veterinary Institute (Uppsala, Sweden) were asked to participate if NAS was identified in the samples. Participating farmers were asked to resample all udder quarters of the cow once within 1 mo. Regression models were used to investigate associations between NAS and cow factors, udder quarter California mastitis test and SCC, and persistence of IMI. Associations with cow composite milk yield and SCC were also investigated. In total, 671 cows from 201 herds were enrolled in the study, and 19 NAS species were identified, of which the 4 most common were Staphylococcus epidermidis, Staphylococcus simulans, Staphylococcus chromogenes, and Staphylococcus haemolyticus. Persistent IMI was more common in udder quarters with Staphylococcus hyicus and $S$. simulans and less common in those with Staphylococcus saprophyticus IMI. $\beta$-Lactamase production by the different NAS species varied from 0 to $100 \%$. There was a significant association between NAS species and California mastitis test and SCC of udder quarters, and this varied depending on parity. The cow composite milk SCC at the test milking before the initial sample was taken differed significantly with NAS species, but
\end{abstract}

Received July 10, 2017.

Accepted October 6, 2017.

${ }^{1}$ Corresponding author: ann.nyman@vxa.se not at the subsequent test milking. Milk yield - at the test milking before or after the initial sample - did not differ significantly for NAS species. There were no significant associations between milk yield or SCC and persistent NAS IMI. In conclusion, the NAS species affects SCC and persistent IMI differently but not milk yield.

Key words: mastitis, coagulase-negative staphylococci, persistence, antimicrobial susceptibility

\section{INTRODUCTION}

Mastitis in dairy cows causes financial losses for the farmers (Halasa et al., 2007), reduces milk production and quality (Hagnestam et al., 2007; Hagnestam-Nielsen et al., 2009; Forsbäck et al., 2010), and has a negative effect on animal welfare. The financial losses are mainly due to the decreased milk production and quality (Hagnestam et al., 2007; Dürr et al., 2008), treatment costs, increased workload for the farmers, and increased culling (Halasa et al., 2007). In Sweden, about $35 \%$ of firstparity cows and approximately $20 \%$ of older cows suffer from new IMI each year (VäxaSverige, 2016). The most common cause of these infections is Staphylococcus aureus followed by non-aureus staphylococci (NAS; VäxaSverige, 2016). In subclinical mastitis, NAS is also the second most frequent finding after $S$. aureus (Persson et al., 2011) in Swedish dairy cows. In other countries (e.g., Finland, the Netherlands, Germany, and South Africa), NAS is the most prevalent finding in mastitis (Pitkälä et al., 2004; Tenhagen et al., 2006; Petzer et al., 2009; Sampimon et al., 2009).

Non-aureus staphylococci are a heterogeneous group of bacterial species. More than 50 species and subspecies have been identified (LPSN, 2017), of which 20 are commonly found in cow milk (Vanderhaeghen et al., 2015). The main reason for not differentiating the NAS previously has been lack of reliable and efficient methods. Phenotypic identification with commercial kits has shown limited typeability and accuracy (Thorberg and Brändström, 2000; Taponen et al., 2006; Capurro, 
2009). Techniques based on molecular identification have mostly been available only in research laboratories, but matrix-assisted laser desorption/ionization time-of-flight (MALDI-ToF) MS analysis is becoming more common. At the National Veterinary Institute in Uppsala, Sweden, MALDI-ToF MS has been used in routine analysis of milk samples since 2013. With this technology, most NAS isolates can be identified at species level with high accuracy (Cameron et al., 2017; Pizauro et al., 2017) within minutes and at a low cost per isolate.

Previously, NAS was believed to mainly cause subclinical or sometimes mild clinical mastitis, but more recent research shows that IMI with NAS can cause chronic mastitis, damage udder tissue, and decrease milk production (Taponen et al., 2007; Thorberg et al., 2009). Less is known about how the specific NAS species affects udder health (Sampimon et al., 2009; Thorberg et al., 2009; Supré et al., 2011). Some virulence genes are present for some species but not for others (Martins et al., 2017), and their susceptibility to antimicrobials varies (Persson Waller et al., 2011; Raspanti et al., 2016; Taponen et al., 2016). Moreover, the knowledge about the distribution and epidemiology of NAS species in Sweden is sparse. Hence, the objective of the present study was to investigate the most commonly found NAS IMI of Swedish dairy cows with suspected subclinical mastitis and how the species are associated with cow factors, antimicrobial susceptibility ( $\beta$-lactamase production), SCC, milk yield, and persistence of IMI.

\section{MATERIALS AND METHODS}

\section{Recruitment of Farmers and Herds}

All dairy farmers who submitted quarter milk samples because of suspected subclinical mastitis to the National Veterinary Institute (Uppsala, Sweden) between September 2014 and May 2015 were contacted by phone to join this cross-sectional study if NAS was identified in the routine analysis. Participating farmers had to be affiliated with the Swedish Official Milk Recording Scheme (SOMRS), and the cow should not have been treated with antimicrobials between sampling and recruitment. Participating farmers were asked to resample all udder quarters of the cows from which the initial sample came within 2 wk after recruitment. The sample sent in before the actual study started is hereafter called the initial sample, and the subsequent resamples are called the follow-up samples. To show the distribution of the participating herds in relation to the density of Swedish dairy herds, a map was created using ArcMap 10.3.10 (Esri Inc., Redlands, CA).

\section{Follow-Up Sampling}

Sterile milk tubes, disinfectant, cotton swabs, and a referral for each cow were sent to the participating farmers. Instructions on aseptic milk sampling and sample storage were also included. The farmers were urged to send the samples in a padded postal envelope to the National Veterinary Institute on the same day as sampling.

\section{Laboratory Analyses}

All samples containing enough milk were investigated on the day of arrival with the California mastitis test (CMT). Moreover, milk aliquots from a randomly selected subsample were analyzed for SCC 2 to $3 \mathrm{~d}$ later using the DeLaval cell counter (DeLaval International AB, Tumba, Sweden). Bacteriological analysis of quarter milk samples and MALDI-ToF identification of the NAS species were performed according to the accredited routines at the National Veterinary Institute. Only colonies from quarter milk samples with growth of bacteria in pure culture were investigated. Criteria for species identification were as follows: a score of $\geq 2$ indicated identification at species level, a score of 1.80 to 1.99 indicated identification at genus level, and a score of $<1.80$ indicated no identification. Species identification was performed using a custom-made database including the Bruker databases no. 5627 and 5989 with addition of custom-made spectrums (MSP) for some NAS species (2 Staphylococcus devriesei MSP, 3 Staphylococcus pseudintermedius MSP, 2 Staphylococcus rostri MPS, 1 Staphylococcus fleuretti MSP, and 1 Staphylococcus lentus Puerto Rico MSP). The genotypic or phenotypic characteristics of the NAS strains were not investigated. $\beta$-Lactamase production was evaluated by the clover-leaf method (Franklin and Wierup, 1982). For Swedish conditions, $\beta$-lactamase resistance is the most important aspect of antimicrobial resistance of staphylococci; hence, resistance to other antimicrobials was not investigated.

\section{Cow Data}

Individual cow data (breed, parity, and day of calving) were obtained from the SOMRS as well as the SCC, milk yield $(\mathrm{kg} / \mathrm{d})$, percentage of fat and protein in milk, and concentration of milk urea $(\mathrm{mmol} / \mathrm{L})$ for all test milkings during 6 mo pre- to 1 yr postrecruitment.

\section{Statistical Analyses}

NAS Distribution in Initial Sample and Associations with Cow Factors. Descriptive statistics 
were used to summarize, at udder quarter level, the distribution of the 19 NAS species identified in the initial sample and their $\beta$-lactamase production. The distribution of the 7 most common NAS species was summarized at cow and herd level as well as for udder quarter CMT, udder quarter SCC, breed [Swedish Red $(\mathbf{S R})$, Swedish Holstein $(\mathbf{S H}), \mathrm{SH} \times \mathrm{SR}$ cross-breed, other breeds], parity (first, second, and third and older), and DIM. Associations between NAS species (dependent variable) in udder quarter milk samples and breed (including only the SH and SR breeds), parity, and DIM (independent variables) were investigated using univariable multinomial logistic regression analyses. Herd was included as a cluster variable (allowing intragroup correlation for the standard errors).

Follow-Up Samples and Persistence of IMI. To investigate persistence of IMI, a new dependent variable was created. Udder quarters with the same NAS species in the first follow-up sample as in the initial sample were scored as persistent IMI; udder quarters without bacteria in the first follow-up sample were scored as nonpersistent IMI. Then, to investigate the association between persistent IMI (dependent variable) and NAS species in the initial sample (independent variable), a multivariable multilevel mixed-effect logistic regression model was used, with herd as random effect and with an identity covariance structure. The number of days from first sampling to follow-up sampling was also included in the model, as this could influence the probability of finding the same NAS species in the same udder quarter.

Associations Between NAS Species and CMT and SCC at Quarter Level: Initial Sample. Associations between CMT (dependent variable) and NAS species (independent variable) were investigated using multivariable mixed-effect ordered logistic regression analysis, where herd and cow were included as random effects and an identity covariance structure (equal variances for random effects; all covariances are zero) was used. The independent variables breed and parity were included as potential confounders; all 2-way interactions between main effects were tested. The associations between SCC (dependent variable) and NAS species (independent variable) were investigated in a similar manner except that a multivariable mixed-effect linear regression model was used.

Associations Between NAS Species and SCC and Milk Yield at Cow Level. To investigate the associations between the initial sample NAS species and cow composite SCC (CSCC) and milk yield at the test milkings before and after this initial sampling, the data had to be transformed to cow level. This was done by classifying cows as having a certain NAS species if no other udder quarter had findings or if other udder quarters had only findings of the same NAS species. Multivariable multilevel mixed-effect linear regression models were then used with CSCC (transformed using the natural logarithm; lnCSCC) or milk yield as the dependent variable. The independent variables were NAS species, number of quarters with the same NAS finding (1-4), breed, parity, DIM, percentage of protein and fat in milk, concentration of milk urea $(\mathrm{mmol} / \mathrm{L})$, and number of days from test milking to sampling (0-65). Moreover, in the lnCSCC model, milk yield was also included as an independent variable, as was $\operatorname{lnC}$ SCC in the milk yield model. In both models, herd was included as random effect, and an identity covariance structure was used.

Associations Between Persistent IMI and Repeated Measurements of SCC and Milk Yield at Cow Level. To assess long-term effects on CSCC and milk yield in cows with persistent IMI and those without, multivariable multilevel mixed-effect linear regression models were used. The lnCSCC or milk yield was included as the dependent variable, and the independent variables were species-specific persistent IMI, number of quarters (1-4) with the same NAS finding in the initial and follow-up samples, breed, parity, DIM, percentages of protein and fat in milk, concentration of milk urea $(\mathrm{mmol} / \mathrm{L})$, and number of days from sampling to test milking and between initial sampling and follow-up sampling. Moreover, in the lnCSCC model, milk yield was also included as an independent variable, and in the milk yield model, $\operatorname{lnCSCC}$ was included as an independent variable. In both models, herd and cow were included as random effects and an identity covariance structure was used. The dependent variables, CSCC and milk yield, were measured at 3 test milkings after the initial sampling. Criteria for inclusion as persistent IMI were (1) repeated findings of the same NAS species in the same udder quarter and no bacteria in the other quarters or (2) findings of the same NAS species in 1 or more udder quarters. Cows with no bacterial findings in any quarter in the first follow-up sample were included as cows with nonpersistent IMI. Only cows with information about both milk yield and CSCC at all 3 test milkings after the initial sampling were included in the statistical analyses. Cows that had been treated with antimicrobials between the recruitment and follow-up sample were excluded.

Common Features of the Statistical Analyses. Only the 7 most prevalent NAS species were included in the statistical analyses, as the number of observations was too small for the other species. Many of the statistical analyses used mixed-effect models to account for cows being more similar within than between herds. As it was most common that the cows only had 1 udder quarter with NAS in the initial sample, we could not 
take into account the random effect of udder quarter within cow.

In all multivariable models, continuous independent variables were assessed if they were linearly related to the outcome by visual examination (using the lowess command in Stata; release 13.1; StataCorp LP, College Station, TX). If they did not seem linearly related, they were either categorized using percentiles as cut-offs or transformed using the natural logarithm, Box-Cox transformation, or fractional polynomial regression. All multivariable models used a manual, stepwisebackward variable selection procedure in which the initial model included all independent variables as main effects. Collinearity between the independent variables was assessed pairwise by Spearman rank correlations. If proof of collinearity $(\mathrm{r} \geq 0.70)$ was present, the variable with the lowest $P$-value in the univariable analysis was selected. All plausible 2-way interactions between the significant main effects were tested. Variables with a significant association $(P<0.05)$ with the dependent variable were kept in the model. Diagnostic plots were visually examined to assess the model fit of the multivariable analyses according to Dohoo et al. (2010). All statistical analyses were performed using Stata (Stata Statistical Software: Release 13.1; StataCorp LP).

\section{RESULTS}

\section{Herds and Herd Characteristics}

In total, 217 farmers were contacted to participate; of these, 201 agreed and 180 (90\%) provided the follow-up sample. The remaining 21 farmers did not take any follow-up samples even after several reminders. The distribution of the participating herds across Sweden in relation to the Swedish dairy herd density is presented in Appendix Figure A1. Among the 201 participating farmers, 178 gave us permission to use their SOMRS data. The missing farmers included the 21 farmers that did not send any follow-up sample and 2 additional farmers.

The yearly median herd size of the 178 herds with complete data was 98 cows [interquartile range (IQR) $=68-164]$, the yearly mean milk production was 9,958 $\mathrm{kg}$ of milk ( $\mathrm{SD}=1,011 \mathrm{~kg}$ of milk), and the yearly median bulk milk SCC was 232,000 cells $/ \mathrm{mL}$ (IQR = 200,000-288,000 cells/mL) during the period September 2014 to August 2015. During the same period, the yearly average herd size of all herds affiliated with the SOMRS ( $\mathrm{n}=3,068$ herds; i.e., $83 \%$ of the dairy cows in Sweden) was 83 cows, the yearly average milk production was $9,611 \mathrm{~kg}$ of milk, and the yearly geometric bulk milk SCC was 193,000 cells/mL.

\section{Cows and Cow Characteristics}

From the 201 herds, 671 cows were recruited (1-21 cows/herd). Data from the SOMRS were available for 611 of these cows from 178 of the herds. A follow-up sample was received from 521 of the 671 cows.

Breed distribution for the 611 cows was $46 \% \mathrm{SH}, 34 \%$ $\mathrm{SR}, 5 \% \mathrm{SH} \times \mathrm{SR}$ cross-breeds, and $15 \%$ other breeds or other cross-breeds. Parity distribution was $38 \%$ first, $25 \%$ second, and $37 \%$ third or more. On average, the cows were 140 DIM (SD $=103$; median $=118$ DIM; $\mathrm{IQR}=51-219$ DIM) when the initial sample was taken.

\section{Quarter Milk Samples}

From the 671 recruited cows 1,191 initial udder quarter milk samples were received (samples were submitted from 1 to 4 quarters/cow), and NAS was detected in 790 of these samples. Data from the SOMRS were available for 611 of the cows representing 712 of these quarter milk samples. From the 521 cows with followup samples, 2,032 udder quarter milk samples were received. The follow-up sample was submitted on average $32 \mathrm{~d}$ after the initial sampling $(\mathrm{SD}=26$; median $=27$ $\mathrm{d} ; \mathrm{IQR}=19-35 \mathrm{~d})$.

\section{NAS Distribution in the Initial Sample}

The NAS bacteria were identified in $783(66 \%)$ of the 1,191 initial quarter milk samples. These findings, and the prevalence of $\beta$-lactamase production, are presented in Table 1. A total of 19 NAS species were identified in the initial samples, of which the most common was Staphylococcus epidermidis followed by Staphylococcus simulans, Staphylococcus chromogenes, and Staphylococcus haemolyticus. In total, $33 \%$ of all NAS isolates produced $\beta$-lactamase, but there was great variation. For example, all Staphylococcus xylosus isolates produced $\beta$-lactamase, but none of the S. simulans or Staphylococcus hyicus isolates did.

At the initial sampling, most cows $(85 \% ; 571 / 671)$ had NAS in only 1 udder quarter; 89 cows had NAS in 2 quarters, 10 cows had NAS in 3 quarters, and 1 cow had NAS in all 4 quarters. Among cows $(\mathrm{n}=100)$ with NAS findings in more than 1 udder quarter, 61 cows had more than 1 NAS species.

The cow-level ( $\mathrm{n}=671$ cows) NAS distribution was $28 \%$ for S. epidermidis, $22 \%$ for S. simulans, $20 \%$ for S. chromogenes, $15 \%$ for S. haemolyticus, $4 \%$ for $S$. xylosus, $4 \%$ for Staphylococcus saprophyticus, and $4 \%$ for S. hyicus. At the herd level (n= 201 herds), S. epidermidis was found in $41 \%$ of the herds, S. simulans in $42 \%$ of the herds, S. chromogenes in $40 \%$ of the herds, 
Table 1. Distribution (number and percentage of samples) of non-aureus staphylococci (NAS) species and $\beta$-lactamase production $(\beta+)$ in 783 udder quarter milk samples from 671 cows (1-4 udder quarter milk samples/cow; 201 herds) with suspected subclinical mastitis ${ }^{1}$

\begin{tabular}{|c|c|c|c|c|}
\hline \multirow[b]{2}{*}{ Staphylococci } & \multicolumn{2}{|c|}{ Distribution of isolates } & \multicolumn{2}{|c|}{$\beta+$} \\
\hline & No. & $\%$ & No. & $\%$ \\
\hline Staphylococcus epidermidis & 206 & 26 & 86 & $\overline{42}$ \\
\hline Staphylococcus simulans & 169 & 22 & 0 & 0 \\
\hline Staphylococcus chromogenes & 148 & 19 & 29 & 20 \\
\hline Staphylococcus haemolyticus & 110 & 14 & 66 & 60 \\
\hline Staphylococcus saprophyticus & 32 & 4 & 28 & 87 \\
\hline Staphylococcus xylosus & 31 & 4 & 31 & 100 \\
\hline Staphylococcus hyicus & 25 & 3 & 0 & 0 \\
\hline Staphylococcus sciuri & 12 & 2 & 2 & 17 \\
\hline Staphylococcus capitis & 9 & 1 & 0 & 0 \\
\hline Staphylococcus warneri & 6 & 1 & 2 & 33 \\
\hline Staphylococcus equorum & 5 & 1 & 3 & 60 \\
\hline Staphylococcus succinus & 2 & $<1$ & 2 & 100 \\
\hline Staphylococcus cohnii & 2 & $<1$ & 0 & 0 \\
\hline Staphylococcus rostri & 2 & $<1$ & 1 & 50 \\
\hline Staphylococcus lentus & 1 & $<1$ & 0 & 0 \\
\hline Staphylococcus fleuretti & 1 & $<1$ & 0 & 0 \\
\hline Staphylococcus hominis & 1 & $<1$ & 1 & 100 \\
\hline Staphylococcus pasteuri & 1 & $<1$ & 0 & 0 \\
\hline Staphylococcus caprae & 1 & $<1$ & 0 & 0 \\
\hline NAS but species not confirmed & 19 & 2 & 12 & 63 \\
\hline Total & 783 & 100 & 263 & 34 \\
\hline
\end{tabular}

${ }^{1}$ The NAS are ordered according to prevalence.

S. haemolyticus in $35 \%$ of the herds, S. saprophyticus in $9 \%$ of the herds, S. xylosus in $11 \%$ of the herds, and $S$. hyicus in $11 \%$ of the herds. The within-herd number of NAS species varied from 1 to 6 .

\section{Associations Between NAS IMI at Udder Quarter Level and Cow Factors}

Of the 712 initial quarter milk samples for which parity data were available, $38 \%$ came from first-parity cows, $25 \%$ came from second-parity cows, and $37 \%$ came from cows in the third parity or more. Moreover, $46 \%$ of the samples came from cows of the SH breed, $34 \%$ from the SR breed, $5 \%$ from the $\mathrm{SH} \times \mathrm{SR}$ cross- breed, and $15 \%$ from other breeds or other cross-breeds. The median DIM was 122 (IQR $=52-225$ DIM) at sampling. The distribution of samples with the 7 most common NAS species over parity, breed, and DIM is summarized in Table 2. Only the SH and SR breeds were included, as there were too few observations for the other breed categories.

The multinomial regression analysis showed significant associations between NAS species and parity, breed, and DIM. Staphylococcus chromogenes was more common than other NAS in first-parity cows compared with third-parity cows $(P \leq 0.001)$. Staphylococcus chromogenes was also more common than S. epidermidis, S. simulans, S. haemolyticus, or S. saprophyticus for

Table 2. Distribution (number and percentage of observations or median and interquartile range; IQR) of udder quarter milk samples, with findings of the 7 most common non-aureus staphylococci (NAS) species with respect to parity ( $\mathrm{n}=658$ samples), breed [Swedish Holstein (SH), Swedish Red (SR); $\mathrm{n}=526$ samples], and DIM $(\mathrm{n}=658 \text { samples })^{1}$

\begin{tabular}{|c|c|c|c|c|c|c|}
\hline \multirow[b]{2}{*}{ Staphylococci } & \multicolumn{3}{|c|}{ Parity, no. (\%) } & \multicolumn{2}{|c|}{ Breed, no. (\%) } & \multirow[b]{2}{*}{ DIM, median (IQR) } \\
\hline & 1 & 2 & $\geq 3$ & $\mathrm{SH}$ & SR & \\
\hline Staphylococcus simulans & $52(32)$ & $40(25)$ & $69(43)$ & $67(51)$ & $48(49)$ & $124(48-227)$ \\
\hline Staphylococcus chromogenes & $100(72)$ & $26(19)$ & $13(9)$ & $56(54)$ & $48(46)$ & $79(29-201)$ \\
\hline Staphylococcus haemolyticus & $26(25)$ & $35(34)$ & $42(41)$ & $63(75)$ & $21(25)$ & $143(80-230)$ \\
\hline Staphylococcus saprophyticus & $7(25)$ & $8(29)$ & $13(46)$ & $16(59)$ & $11(41)$ & $139(60-208)$ \\
\hline Total & $250(38)$ & $170(26)$ & $238(32)$ & $305(58)$ & $221(42)$ & \\
\hline
\end{tabular}

${ }^{1}$ The NAS are ordered according to prevalence. 


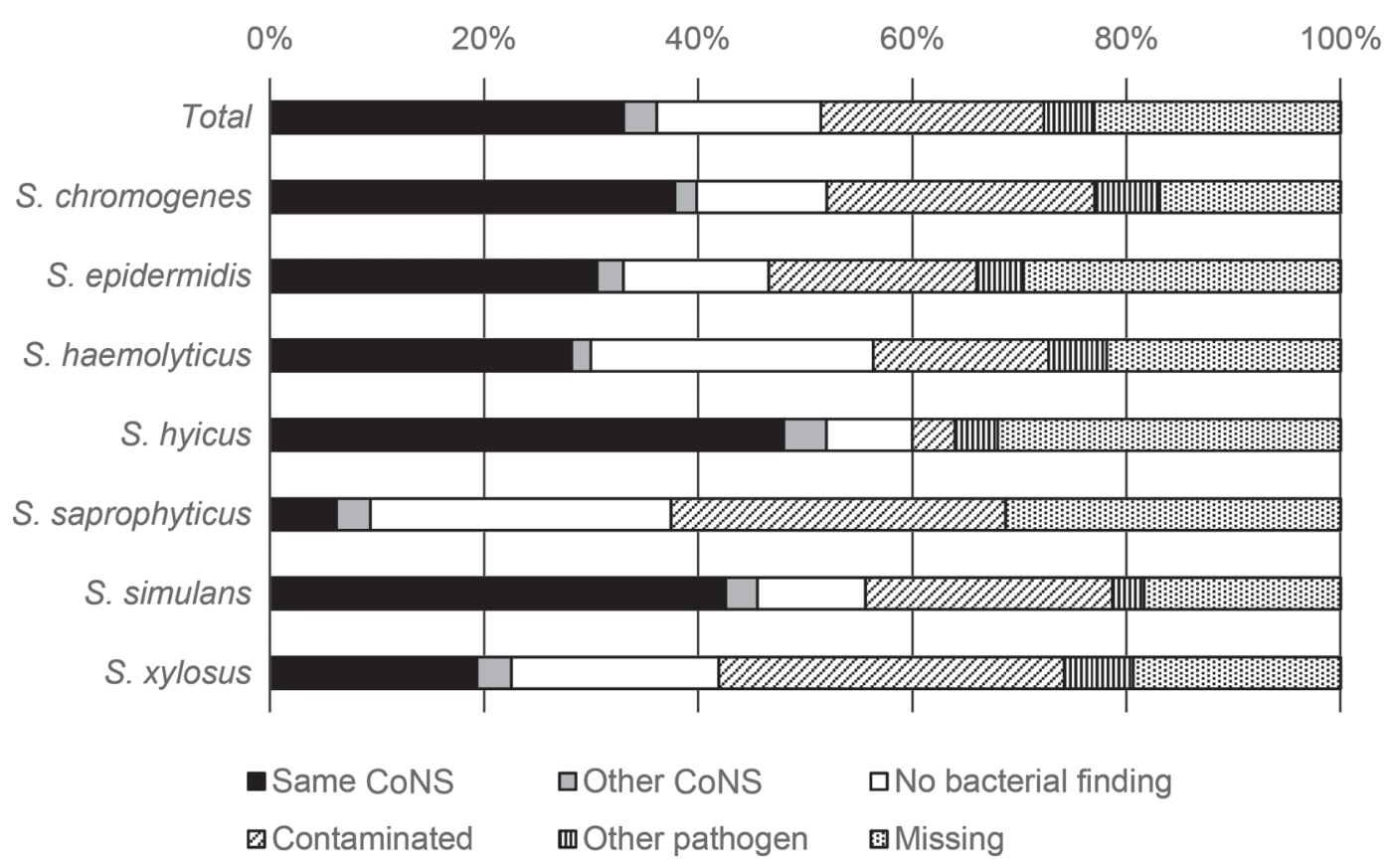

Figure 1. Percentages of udder quarters $(\mathrm{n}=783)$ at follow-up sampling with the same non-aureus staphylococci (NAS) species (black) as in the initial sample, other NAS species (gray), no bacterial finding (white), contaminated (diagonal lines), other pathogens (vertical lines), or not sent in (missing; dots), presented per initial NAS finding and in total.

first-parity cow samples compared with second-parity cow samples $(P<0.001$ to $P=0.03)$. Staphylococcus xylosus was more common than $S$. epidermidis in first parity compared with third or more parity $(P=0.05)$.

The overall association between NAS and breed was not significant $(P=0.06)$, but $S$. haemolyticus was more common than $S$. epidermidis, $S$. simulans, or $S$. chromogenes in $\mathrm{SH}$ samples compared with SR samples $(P=0.007$ to $P \leq 0.02)$. The overall association between NAS and DIM was not significant $(P=0.06)$ either, but $S$. chromogenes was less common than $S$. epidermidis or $S$. haemolyticus with increasing DIM ( $P$ $=0.02$ and $P=0.01$, respectively).

\section{NAS in the Follow-Up Samples and Persistence of IMI}

The same NAS species as in the initial sample was the main finding in the follow-up samples in $33 \%$ of the initial 783 udder quarter samples (Figure 1). The proportion of samples with persistent IMI differed depending on the NAS species (Figure 1). The highest percentages of persistent infection, 48 and $43 \%$, were seen for S. hyicus and S. simulans, respectively. The lowest percentages were for $S$. xylosus and S. saprophyticus, where a persistent infection was found in 19 and $6 \%$ of the quarters, respectively.

The multivariable mixed-effect logistic regression model showed a significant association between persis- tent IMI and NAS species. The odds ratio of persistent $S$. saprophyticus IMI was significantly lower than that of persistent IMI with $S$. epidermidis $(P=0.04$, OR $=$ 11, 95\% CI: $2-58)$, S. simulans $(P=0.001, \mathrm{OR}=18$, 95\% CI: 3-96), S. chromogenes $(P=0.003, \mathrm{OR}=12$, 95\% CI: 2-65), S. haemolyticus $(P=0.02, \mathrm{OR}=8.00$, 95\% CI: $1.00-43.0)$, or S. hyicus $(P<0.001$, OR $=45$, 95\% CI: 6-337). The odds ratio of persistent $S$. hyicus IMI was significantly higher than that of persistent IMI with $S$. epidermidis $(P=0.03$, OR $=0.25,95 \%$ CI: $0.07-0.87), S$. chromogenes $(P=0.05, \mathrm{OR}=0.27,95 \%$ CI: 0.08-0.97), S. haemolyticus $(P=0.01$, OR $=0.18$, 95\% CI: $0.05-0.66)$, or $S$. xylosus $(P=0.007$, OR $=$ $0.11,95 \%$ CI: $0.02-0.55$ ). The odds ratio of persistent $S$. simulans IMI was significantly higher than that of persistent IMI with $S$. haemolyticus $(P=0.01$, OR $=$ $0.44,95 \%$ CI: $0.23-0.85)$ or $S$. xylosus $(P=0.03$, OR $=$ $0.28,95 \%$ CI: $0.09-0.86)$. Number of days from initial sampling to the follow-up sampling was significantly associated with persistent IMI, with a lower odds ratio for persistent IMI with increasing days from the initial sample $(P=0.02, \mathrm{OR}=0.99,95 \%$ CI: $0.98-1.00)$.

\section{NAS Species and CMT and SCC at Quarter Level: Initial Sample}

In all, 760 udder quarter milk samples were scored using the CMT, giving a median score of 3 (IQR = $3-4)$. The SCC was analyzed in 281 of the quarter milk 
Table 3. California mastitis test $(\mathrm{CMT})$ scores and $\mathrm{SCC}(\times 1,000$ cells $/ \mathrm{mL})$ in quarter milk samples, distributed by non-aureus staphylococci (NAS) species ${ }^{1}$

\begin{tabular}{|c|c|c|c|c|c|c|}
\hline \multirow[b]{2}{*}{ Staphylococci } & \multicolumn{3}{|c|}{$\mathrm{CMT}$} & \multicolumn{3}{|c|}{$\mathrm{SCC}$} \\
\hline & Median & $\mathrm{IQR}$ & No. & Median & $\mathrm{IQR}$ & No. \\
\hline Staphylococcus epidermidis & 3 & $3-4$ & 199 & 1,960 & $1,090-3,314$ & 50 \\
\hline Staphylococcus simulans & 3 & $3-4$ & 167 & 1,263 & $681-2,458$ & 58 \\
\hline Staphylococcus chromogenes & 3 & $3-4$ & 143 & 1,126 & $438-1,826$ & 61 \\
\hline Staphylococcus haemolyticus & 3 & $3-4$ & 108 & 1,801 & $812-2,824$ & 42 \\
\hline Staphylococcus saprophyticus & 3.5 & $3-4$ & 30 & 374 & $167-1,203$ & 18 \\
\hline Staphylococcus xylosus & 3 & $2-4$ & 29 & 432 & $150-1,180$ & 16 \\
\hline Staphylococcus hyicus & 4 & $3-5$ & 24 & 2,048 & $653-3,486$ & 11 \\
\hline Staphylococcus sciuri & 3 & $2-4$ & 11 & - & - & - \\
\hline Staphylococcus capitis & 3 & $3-4$ & 9 & - & - & — \\
\hline Staphylococcus warneri & 3 & $3-3$ & 6 & - & - & - \\
\hline Staphylococcus equorum & 4 & $4-4$ & 5 & - & - & - \\
\hline Total & - & - & 731 & - & - & 256 \\
\hline
\end{tabular}

${ }^{1}$ Median and interquartile range (IQR) and number of observations for CMT and SCC within NAS species are given. Only results for NAS species with $\geq 5$ observations are presented. The NAS are ordered according to prevalence.

samples, giving a median of $1,251,000$ cells/mL (IQR $=539,000-2,613,000$ cells $/ \mathrm{mL})$. The median and IQR of CMT and SCC for each NAS species with at least 5 observations are presented in Table 3.

The multivariable mixed-effect ordered logistic regression analysis of associations between the CMT score of quarter milk samples and NAS species and cow factors (639 observations; parity information was not available for all cows) showed a significant interaction between parity and NAS species $(P=0.001$; Appendix Table A1). The details of this interaction are described below.

Between parities, for udder quarters with S. epidermidis, the probability of high CMT was higher for cows in second parity $(P=0.004)$ and third parity or more $(P<0.001)$ than for cows in first parity. For udder quarters with $S$. simulans, the probability of high CMT was higher for second-parity cows than for first-parity cows $(P=0.049)$. For udder quarters with $S$. hyicus, the probability of high CMT was higher for first-parity cows than for second-parity cows $(P=0.03)$. For udder quarters with $S$. chromogenes, $S$. haemolyticus, $S$. saprophyticus, or $S$. xylosus, there were no differences in the probability of high or low CMT scores for cows in different parities.

Within parity, for first-parity cows, the probability of high CMT scores was higher for udder quarters with $S$. hyicus than for any other NAS except $S$. saprophyticus $(P=0.02$ to $P=0.001)$. For second-parity cows, the probability of high CMT scores was higher for udder quarters with $S$. epidermidis $(P=0.01)$ or $S$. haemolyticus $(P=0.02)$ than for udder quarters with $S$. chromogenes. For cows in third parity or more, the probability of high CMT scores was higher for udder quarters with
$S$. epidermidis than for those with $S$. simulans $(P=$ $0.01)$, S. chromogenes $(P=0.03)$, or $S$. haemolyticus $(P$ $=0.025)$. No other significant differences were found.

The multivariable mixed-effect linear regression model of associations between quarter milk SCC, NAS species, and cow factors included 237 observations (information about parity was not available for all cows). There was a significant interaction between parity and NAS species $(P<0.001 ;$ Appendix Table A2). The details of this interaction are described below.

Between parities, for udder quarters with S. epidermidis or $S$. simulans, the SCC was higher for cows in second parity $(P=0.03$ and $P=0.002$, respectively $)$ and third parity or more $(P=0.02$ and $P=0.001$, respectively) than for cows in first parity. For udder quarters with $S$. hyicus, the SCC was higher for firstparity cows than for second-parity cows $(P=0.03)$. For udder quarters with $S$. chromogenes, S. haemolyticus, S. saprophyticus, or $S$. xylosus, there were no significant differences for parities.

Within parity, for first-parity cows, the SCC was significantly higher in udder quarters with $S$. hyicus than in quarters with $S$. simulans $(P=0.003)$, S. chromogenes $(P=0.02)$, S. saprophyticus $(P=0.04)$, or $S$. xylosus $(P=0.003)$ and in udder quarters with $S$. haemolyticus than $S$. simulans $(P=0.003)$ or $S$. xylosus $(P=0.008)$. For second-parity cows, the SCC was significantly higher in udder quarters with $S$. epidermidis than in those with $S$. chromogenes $(P<0.001)$, S. saprophyticus $(P<0.001)$, S. xylosus $(P=0.002)$, or S. hyicus $(P=0.02)$; higher in udder quarters with $S$. simulans than in those with $S$. chromogenes $(P=$ $0.005)$, S. saprophyticus $(P<0.001)$, or $S$. xylosus $(P=$ $0.006)$; higher in udder quarters with $S$. haemolyticus 


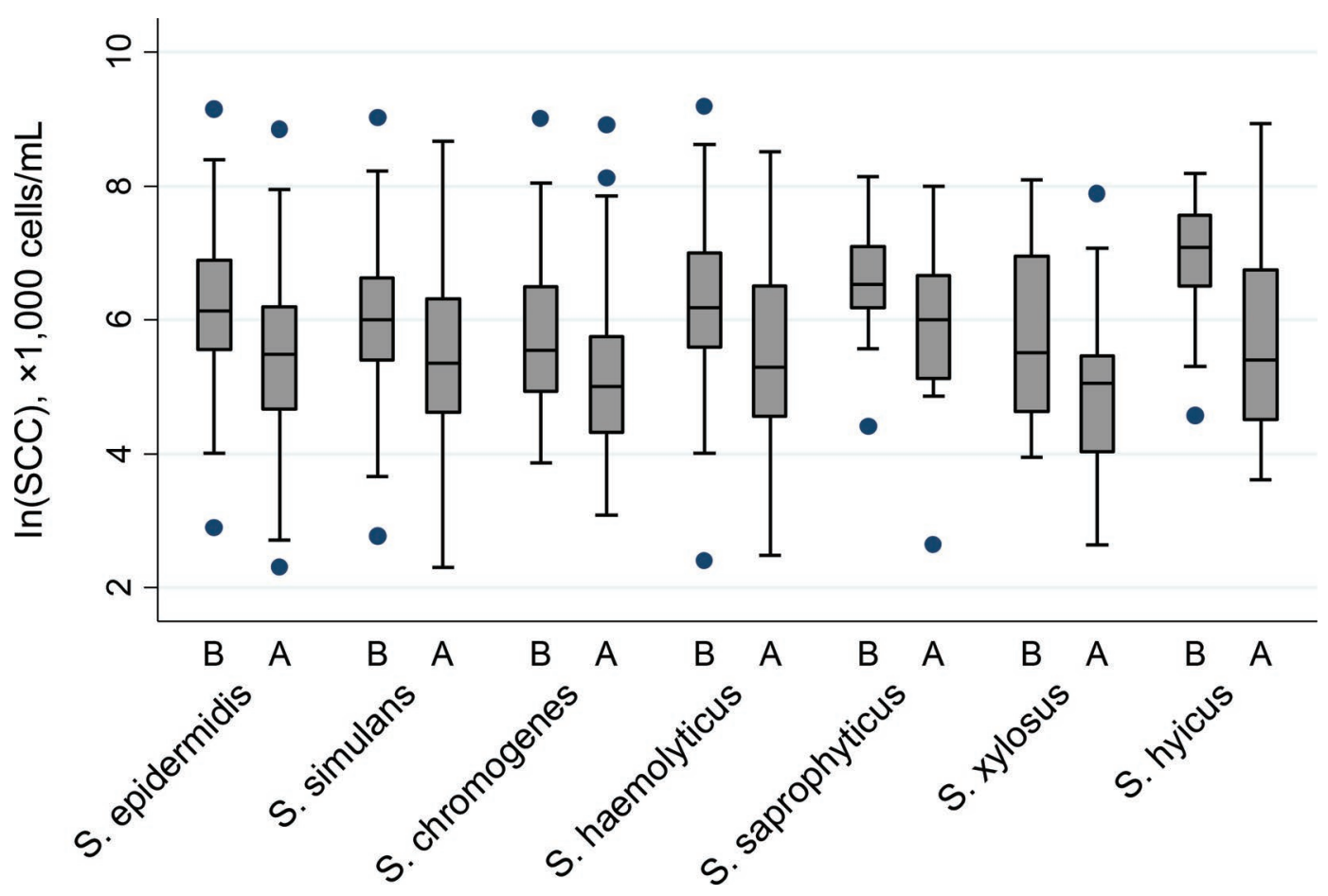

Figure 2. Box plot of cow SCC transformed using the natural logarithm (lnCSCC) at the test milking closest before $(\mathrm{B}, \mathrm{n}=390)$ and after $(\mathrm{A}, \mathrm{n}=381)$ quarter milk sampling for bacterial culturing. Results are presented for cows with findings of the 7 most common non-aureus staphylococci species. The box shows the lower quartile, median, and the upper quartile, and the whiskers show the upper and lower adjacent values (1.5 interquartile range from the lower and upper quartile, respectively). The dots are outliers. Color version available online.

than in those with $S$. chromogenes $(P=0.01)$, S. saprophyticus $(P<0.001)$, or $S$. xylosus $(P=0.01)$; and higher in udder quarters with $S$. chromogenes than in those with $S$. saprophyticus $(P=0.049)$. For cows in third parity or more, the SCC was significantly higher in udder quarters with $S$. epidermidis than in those with $S$. saprophyticus $(P=0.001)$ or $S$. xylosus $(P<$ 0.001 ); in udder quarters with $S$. simulans than in those with $S$. saprophyticus $(P=0.02)$ or $S$. xylosus $(P=$ 0.007 ); and in udder quarters with $S$. haemolyticus than in those with $S$. xylosus $(P=0.04)$.

\section{NAS Species and SCC at Cow Level}

The CSCC at the test milking closest before initial sampling was available for 421 of the 422 cows, with findings of only 1 NAS species in 1 or more udder quarters at the initial sampling. The median CSCC for these 421 cows (0-55 d before sampling) was 363,000 cells $/ \mathrm{mL}(\mathrm{IQR}=205,000-801,000)$. The CSCC at the test milking closest after the initial sampling (1-65 d) was available for 414 cows, with findings of only 1 NAS species in 1 or more udder quarters at the initial sampling. This median CSCC was 175,000 cells $/ \mathrm{mL}$ $(\mathrm{IQR}=84,000-400,000)$. Figure 2 shows a box plot of the CSCC at the test milkings closest before and after initial sampling with respect to NAS species.

The univariable mixed-effect linear regression model showed an overall significant $(P=0.0005)$ association between NAS species and CSCC at the test milking closest before initial sampling; this was also seen in the multivariable analysis (Table 4). Cows with S. chromogenes had a significantly lower CSCC than those with $S$. epidermidis $(P=0.05), S$. haemolyticus $(P=$ $0.01)$, S. saprophyticus $(P=0.005)$, and $S$. hyicus $(P=$ $0.001)$. Cows with $S$. hyicus had a significantly higher CSCC than cows with $S$. epidermidis $(P=0.03)$, $S$. simulans $(P=0.01)$, and $S$. xylosus $(P=0.02)$. Cows with $S$. saprophyticus had a significantly higher CSCC than cows with $S$. simulans $(P=0.03)$ or $S$. xylosus $(P$ $=0.05)$. Moreover, in the multivariable analysis, parity was also significantly associated with CSCC; cows in third parity or more had a significantly higher CSCC than first-parity cows $(P=0.007)$, but there was no significant difference in CSCC between second parity and third parity or more. No other significant associations were seen. No significant associations were found between NAS species and CSCC at the test milking closest after the initial sampling in either the univariable $(P=0.06)$ or multivariable $(P=0.41)$ analyses. 
Table 4. Multivariable mixed-effect linear regression analysis of associations between cow composite SCC (at the test milking closest before quarter milk sampling for bacterial culturing) and non-aureus staphylococci (NAS) as well as between cow composite SCC and parity $(\mathrm{n}=421)$

\begin{tabular}{|c|c|c|c|c|c|}
\hline Variable & $\beta^{1}$ & $\mathrm{SE}(\beta)$ & $\mathrm{LSM}^{2}$ & $95 \%$ CI (LSM) & $P$-value \\
\hline Intercept & 5.59 & 0.12 & - & - & - \\
\hline \multicolumn{6}{|l|}{ NAS species } \\
\hline Staphylococcus chromogenes & Referent & - & 311 & 245-399 & - \\
\hline Staphylococcus epidermidis & 0.31 & 0.16 & 428 & $347-523$ & 0.05 \\
\hline Staphylococcus simulans & 0.20 & 0.16 & 384 & $308-473$ & 0.20 \\
\hline Staphylococcus haemolyticus & 0.43 & 0.17 & 478 & $376-608$ & 0.01 \\
\hline Staphylococcus saprophyticus & 0.76 & 0.27 & 665 & $412-1,075$ & 0.005 \\
\hline Staphylococcus xylosus & 0.10 & 0.26 & 344 & $219-539$ & 0.71 \\
\hline Staphylococcus hyicus & 0.96 & 0.30 & 812 & $473-1,408$ & 0.001 \\
\hline \multicolumn{6}{|l|}{ Parity } \\
\hline 1 & Referent & - & 354 & $296-424$ & - \\
\hline 2 & 0.12 & 0.12 & 403 & $327-493$ & 0.34 \\
\hline$\geq 3$ & 0.33 & 0.12 & 493 & $411-590$ & 0.007 \\
\hline
\end{tabular}

\section{NAS Species and Milk Yield at Cow Level}

In total, 556 cows had a registered milk yield at the test milking closest before initial sampling (0-55 d before sampling); of these, 422 cows had only 1 NAS species in 1 or more udder quarters. The mean milk yield at this test milking was $33.4 \mathrm{~kg}$ of milk ( $\mathrm{SD}=$ $9.8 \mathrm{~kg}$ ), and the median DIM was 125 (IQR $=62-219$ DIM). At the test milking closest after initial sampling, 599 cows had a registered milk yield (1-65 d after the initial sampling), of which 435 had only 1 NAS species in 1 or more udder quarters. The mean milk yield at this test milking was $33.3 \mathrm{~kg}$ of milk ( $\mathrm{SD}=10.0 \mathrm{~kg}$ ), and the median DIM was 134 (IQR $=71-227$ DIM). Figure 3 shows a box plot of the milk yield at the test milking closest before and after initial sampling with respect to NAS species.

The univariable mixed-effect linear regression model showed an overall significant $(P=0.0004)$ association between NAS species and milk yield at the test milking closest before initial sampling. However, when parity was included in the multivariable analysis, the association became nonsignificant $(P=0.10)$. No significant associations were found between NAS species and milk yield at the test milking closest after the initial sampling in either the univariable $(P=0.21)$ or multivariable $(P=0.44)$ analyses.

\section{Persistent IMI and Repeat Measurements of SCC and Milk Yield at Cow Level}

Of the 320 cows with a follow-up sample, only 71 cows had the same NAS species in the same udder quarter (and no other bacterial findings in the other udder quarters except for the same NAS species) and were considered to have a persistent NAS IMI. The CSCC and milk yield of these 71 cows, at the 3 test milkings after the initial sample was taken, were then compared with that of those cows that were considered to not have a persistent NAS IMI $(\mathrm{n}=27$ cows that had an NAS IMI initially but had no findings of bacteria at the follow-up sampling). Hence, the multivariable mixed-effect linear regression models investigating associations between milk yield or CSCC and persistent NAS IMI included 98 cows. No significant association between CSCC or milk yield and persistent IMI at the species level could be seen in either the univariable $(P$ $=0.13$ and $P=0.49$, respectively) or the multivariable ( $P=0.48$ and $P=0.75$, respectively) analyses.

\section{DISCUSSION}

The distribution of NAS species in the present study was similar to the distributions in both a Swedish study (Persson et al., 2011) and a Finnish study (Taponen et al., 2016) of SCM. In all 3 studies, S. epidermidis, S. simulans, S. chromogenes, and S. haemolyticus were the 4 most common NAS species, with $S$. epidermidis or $S$. simulans the most common findings and $S$. chromogenes as the third most common finding. In studies from other countries, S. chromogenes is often the most common NAS species and S. epidermidis is less common (Fry et al., 2014; De Visscher et al., 2015; Raspanti et al., 2016; Condas et al., 2017a). Reasons for the differences between countries have not been investigated, but housing systems, management factors, herd size, climate, and sampling strategy used in the studies could probably explain some of the differences. Moreover, the distribution of NAS species has been shown to change over time (Taponen et al., 2016), so a difference in time 


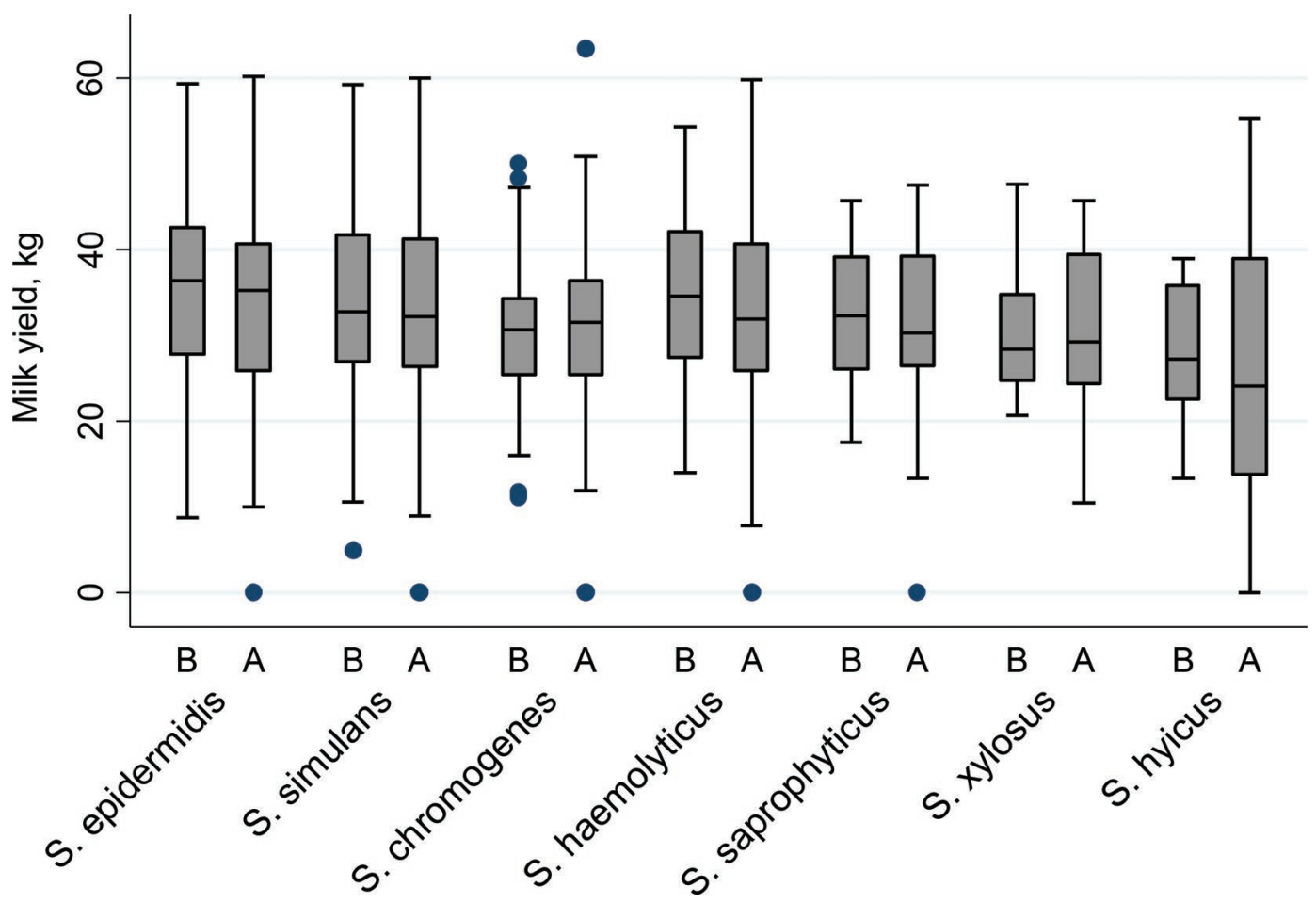

Figure 3. Box plot of milk yield ( $\mathrm{kg}$ of milk) at the test milking closest before $(\mathrm{B}, \mathrm{n}=391)$ and after $(\mathrm{A}, \mathrm{n}=401)$ quarter milk sampling for bacterial culturing. Results are presented for cows with findings of the 7 most common non-aureus staphylococci species. The box shows the lower quartile, median, and the upper quartile, and the whiskers show the upper and lower adjacent values (1.5 interquartile range from the lower and upper quartile, respectively). The dots are outliers. Color version available online.

of introduction of certain NAS species or strains could also be one explanation.

The production of $\beta$-lactamase by the NAS species varied greatly. Our results are in line with several studies that show a high prevalence of $\beta$-lactamase producing $S$. epidermidis and $S$. haemolyticus isolates and a low prevalence of $\beta$-lactamase producing $S$. chromogenes and S. simulans isolates (Sawant et al., 2009; Persson Waller et al., 2011; Taponen et al., 2016). In a study of Sampimon et al. (2011), the prevalence of the blaZ gene (which encodes for penicillin resistance) varied between 20 and $100 \%$ in their NAS isolates $(n=170)$. Reasons for the difference in $\beta$-lactamase production by NAS species are not known, and further genotypic analyses are needed to clarify this. Knowledge about antimicrobial susceptibility is important for making treatment decisions. As the susceptibility varies markedly between NAS species, it is important to test the antimicrobial susceptibility before initiating treatment.

Persistent IMI was present in $33 \%$ of the udder quarters in the present study, and persistent IMI was more common in udder quarters with $S$. hyicus or $S$. simulans than with other NAS species. This finding is in line with Gillespie et al. (2009), who found that most $S$. hyicus, S. simulans, and S. epidermidis isolates had the same pulsed-field gel electrophoresis pattern at multiple samplings. In the study of Thorberg et al. (2009), persistent IMI caused by $S$. chromogenes, S. epidermidis, or $S$. simulans was more common (58-76\%) than in the present study, but like in our findings, persistent IMI were not that common for S. xylosus or S. haemolyticus infections. Others have shown that $S$. chromogenes causes not only persistent IMI (Piessens et al., 2011) but also nonpersistent ones (Gillespie et al., 2009). In the present study, a persistent IMI was seen in almost $40 \%$ of the udder quarters with an initial finding of $S$. chromogenes. However, as no genotyping was done, we cannot be sure that the reisolation of the same NAS species in the same udder indicates a persistent IMI. More studies are needed in which genotypic methods are used to clarify the nature of persistent IMI by the NAS species. Moreover, phenotypic and genotypic characteristics making an NAS species persistent are not well known, but presence of certain virulence genes is probably of importance (Vanderhaeghen et al., 2014).

In the present study, S. chromogenes and S. xylosus were more common in quarter milk samples of cows in first parity than in cows of third parity or more. Others have also found that $S$. chromogenes is more common in udder quarters of first-parity cows (Thorberg et al., 
2009; Mørk et al., 2012; De Visscher et al., 2016a). Why this is so is not clear. De Vliegher et al. (2003) found that teat apices of heifers as young as 11 mo can be colonized with $S$. chromogenes. Those findings were not associated with subclinical mastitis but could represent a risk factor for both IMI and subclinical mastitis. However, colonization of the teat apex by $S$. chromogenes is not exclusive to first-parity cows; it colonizes both dry cows and heifers close to calving (De Visscher et al., 2016b). Dolder et al. (2017) found that udder edema is a risk factor for $S$. chromogenes IMI, which may explain, at least to some extent, why $S$. chromogenes IMI is more common in first-parity cows, as udder edema is more common in pregnant heifers than in older cows (Emery et al., 1969).

The finding that $S$. xylosus was more common in milk samples from first-parity cows than in samples from older ones is in contrast to the study by De Visscher et al. (2015). Their investigation of IMI throughout lactation found that $79 \%$ of the S. xylosus isolates came from multiparous cows and only $21 \%$ came from firstparity cows. However, S. xylosus was more common in first-parity cows than in multiparous cows for IMI at parturition in another study of De Visscher et al. (2016a). To our knowledge, risk factors associated with S. xylosus IMI or SCM have not been investigated, so such studies are warranted.

An unexpected finding was that $S$. haemolyticus was more common in quarter milk samples from the $\mathrm{SH}$ breed than the SR breed. Not many NAS studies have investigated breed, but De Visscher et al. (2016b) found that $S$. devriesei was more common on teat apices of red and white Holstein-Friesian cows than on the black and white ones. More studies are needed to clarify the association between breed and NAS species.

Another finding in our study was that $S$. chromogenes IMI were found earlier in lactation than $S$. epidermidis or S. haemolyticus IMI (at median DIM 79 vs. 129 and 143, respectively). Osterås et al. (2006) found no association between NAS (as a group) IMI and DIM, whereas Condas et al. (2017a) did when investigating different NAS species. Although Condas et al. (2017a) did not compare the NAS species in the same statistical model, their quarter-level prevalence of $S$. chromogenes, S. xylosus, and $S$. haemolyticus increased with increasing DIM, whereas for S. simulans it decreased with increasing DIM (after about 120 DIM). However, because the present study did not follow cows from calving to dry-off with multiple samplings, it is difficult to draw any conclusions about the associations between DIM and NAS species.

In the present study, associations between SCC and NAS species were investigated at both quarter and cow level. At quarter level, the statistical analyses for
CMT and SCC gave approximately the same results for both measurements and showed that the association between NAS species and CMT/SCC differed between parities. In first-parity cows, quarters with $S$. hyicus had higher CMT and SCC scores than quarters with other NAS species and quarters of second-parity cows with S. hyicus. In the study of Fry et al. (2014), the effect of parity was not investigated, but the SCC of quarter milk samples was numerically highest for udder quarters with S. hyicus IMI; however, as they found only 5 quarters with $S$. hyicus IMI, the difference was not statistically significant. However, Condas et al. (2017b) also reported high SCC in quarters with $S$. hyicus IMI. In the present study, both the quarter SCC/ CMT and the CSCC were mostly lower for quarter and whole udder samples with S. chromogenes or S. xylosus, independent of parity. Others have found that the SCC is significantly higher in udder quarters with $S$. chromogenes than in quarters with $S$. xylosus or $S$. cohnii (Fry et al., 2014) or that $S$. chromogenes is associated with both high and low SCC (Condas et al., 2017b). It is possible that different strains of $S$. chromogenes can have different virulence factors and hence induce different inflammatory reactions.

Data on milk production were available only on the whole udder level in the present study, which might explain why no associations between NAS species and milk yield were found. In general, milk yield is reduced at mastitis (Hagnestam et al., 2007; Hagnestam-Nielsen and Østergaard, 2009); however, our results are in line with a study by Tomazi et al. (2015), who investigated effects of $S$. chromogenes IMI on milk production and composition. Moreover, although the SCC differed significantly, Pearson et al. (2013) could not find any differences in composite milk yield or composition for monozygotic twin heifers with or without NAS IMI at calving. Nevertheless, Thorberg et al. (2009) found that milk yield differed between healthy cows and cows with persistent or nonpersistent NAS IMI on a species level; in general, healthy cows and cows with persistent IMI had higher milk production than those with nonpersistent IMI.

\section{CONCLUSIONS}

In total, 19 different NAS species were identified, but 4 of these-S. epidermidis, S. simulans, S. chromogenes, and $S$. haemolyticus - accounted for $81 \%$ of the quarter milk findings. $\beta$-Lactamase production varied from 0 to $100 \%$ for the different NAS species. Persistent IMI was more commonly caused by S. hyicus and S. simulans isolates, whereas $S$. saprophyticus more often caused nonpersistent IMI. The SCC, both in quarter and composite milk samples, differed depending on NAS 
species, but this difference varied within and between parities. The species of NAS made no difference in milk yields. The results of this study will improve the advisory services at the National Veterinary Institute for aiding advisors and farmers in the control of IMI caused by different NAS species.

\section{ACKNOWLEDGMENTS}

The authors gratefully acknowledge the financial support from the Swedish Farmers' Foundation for Agricultural Research (Stockholm, Sweden). We also thank all the participating farmers for their cooperation and the technical staff at the laboratory at the Department of Animal Health and Antimicrobial Strategies (National Veterinary Institute, Uppsala, Sweden) and at the Department of Bacteriology (National Veterinary Institute).

\section{REFERENCES}

Cameron, M., H. W. Barkema, J. De Buck, S. De Vliegher, M. Chaffer, J. Lewis, and G. P. Keefe. 2017. Identification of bovine-associated coagulase-negative staphylococci by matrix-assisted laser desorption/ionization time-of-flight mass spectrometry using a direct transfer protocol. J. Dairy Sci. 100:2137-2147. https://doi.org/10 $.3168 /$ jds.2016-12020.

Capurro, A. 2009. Diagnostic and epidemiological studies of staphylococci in bovine mastitis. PhD Diss. Swedish University of Agricultural Sciences, Uppsala.

Condas, L. A. Z., J. De Buck, D. B. Nobrega, D. A. Carson, S. Naushad, S. De Vliegher, R. N. Zadoks, J. R. Middleton, S. Dufour, J. P. Kastelic, and H. W. Barkema. 2017a. Prevalence of non-aureus staphylococci species causing intramammary infections in Canadian dairy herds. J. Dairy Sci. 100:5592-5612. https://doi.org/10 .3168/jds.2016-12478.

Condas, L. A. Z., J. De Buck, D. B. Nobrega, D. A. Carson, J. P. Roy, G. P. Keefe, T. J. DeVries, J. R. Middleton, S. Dufour, and H. W. Barkema. 2017b. Distribution of non-aureus staphylococci species in udder quarters with low and high somatic cell count, and clinical mastitis. J. Dairy Sci. 100:5613-5627. https://doi.org/10.3168/ jds.2016-12479.

De Visscher, A., S. Piepers, F. Haesebrouck, and S. De Vliegher. 2016a. Intramammary infection with coagulase-negative staphylococci at parturition: Species-specific prevalence, risk factors, and effect on udder health. J. Dairy Sci. 99:6457-6469. https://doi .org/10.3168/jds.2015-10458.

De Visscher, A., S. Piepers, F. Haesebrouck, and S. De Vliegher. 2016b. Teat apex colonization with coagulase-negative Staphylococcus species before parturition: Distribution and species-specific risk factors. J. Dairy Sci. 99:1427-1439. https://doi.org/10.3168/ jds.2015-10326.

De Visscher, A., S. Piepers, K. Supre, F. Haesebrouck, and S. De Vliegher. 2015. Short communication: Species group-specific predictors at the cow and quarter level for intramammary infection with coagulase-negative staphylococci in dairy cattle throughout lactation. J. Dairy Sci. 98:5448-5453. https://doi.org/10.3168/jds .2014-9088.

De Vliegher, S., H. Laevens, L. A. Devriese, G. Opsomer, J. L. Leroy, H. W. Barkema, and A. de Kruif. 2003. Prepartum teat apex colonization with Staphylococcus chromogenes in dairy heifers is associated with low somatic cell count in early lactation. Vet. Microbiol. $92: 245-252$.
Dolder, C., B. H. P. van den Borne, J. Traversari, A. Thomann, V. Perreten, and M. Bodmer. 2017. Quarter- and cow-level risk factors for intramammary infection with coagulase-negative staphylococci species in Swiss dairy cows. J. Dairy Sci. 100:5653-5663. https://doi.org/10.3168/jds.2016-11639.

Dohoo, I., W. Martin, and H. Stryhn. 2010. Veterinary Epidemiologic Research. 2nd ed. VER Inc., Charlottestown, PEI, Canada.

Dürr, J. W., R. I. Cue, H. G. Monardes, J. Moro-Méndez, and K. M. Wade. 2008. Milk losses associated with somatic cell counts per breed, parity and stage of lactation in Canadian dairy cattle. Livest. Sci. 117:225-232. https://doi.org/10.1016/j.livsci.2007.12.004.

Emery, R. S., H. D. Hafs, D. Armstrong, and W. W. Snyder. 1969. Prepartum grain feeding effects on milk production, mammary edema, and incidence of diseases. J. Dairy Sci. 52:345-351.

Forsbäck, L., H. Lindmark-Månsson, A. Andrén, and K. SvennerstenSjaunja. 2010. Evaluation of quality changes in udder quarter milk from cows with low-to-moderate somatic cell counts. Animal 4:617-626. https://doi.org/10.1017/S1751731109991467.

Franklin, A., and M. Wierup. 1982. Evaluation of the Sensititre method adapted for antimicrobial drug susceptibility testing in veterinary medicine. Vet. Microbiol. 7:447-454.

Fry, P. R., J. R. Middleton, S. Dufour, J. Perry, D. Scholl, and I. Dohoo. 2014. Association of coagulase-negative staphylococcal species, mammary quarter milk somatic cell count, and persistence of intramammary infection in dairy cattle. J. Dairy Sci. 97:48764885. https://doi.org/10.3168/jds.2013-7657.

Gillespie, B. E., S. I. Headrick, S. Boonyayatra, and S. P. Oliver. 2009. Prevalence and persistence of coagulase-negative Staphylococcus species in three dairy research herds. Vet. Microbiol. 134:65-72. https://doi.org/10.1016/j.vetmic.2008.09.007.

Hagnestam, C., U. Emanuelson, and B. Berglund. 2007. Yield losses associated with clinical mastitis occurring in different weeks of lactation. J. Dairy Sci. 90:2260-2270.

Hagnestam-Nielsen, C., U. Emanuelson, B. Berglund, and E. Strandberg. 2009. Relationship between somatic cell count and milk yield in different stages of lactation. J. Dairy Sci. 92:3124-3133. https:// doi.org/10.3168/jds.2008-1719.

Hagnestam-Nielsen, C., and S. Østergaard. 2009. Economic impact of clinical mastitis in a dairy herd assessed by stochastic simulation using different methods to model yield losses. Animal 3:315-328. https://doi.org/10.1017/S1751731108003352.

Halasa, T., K. Huijps, O. Østerås, and H. Hogeveen. 2007. Economic effects of bovine mastitis and mastitis management: A review. Vet. Q. 29:18-31. https://doi.org/10.1080/01652176.2007.9695224.

LPSN. 2017. LPSN - List of prokaryotic names with standing in nomenclature. Vol. 2017. A. C. Parte, ed. Accessed June 3, 2017. http://www.bacterio.net/.

Martins, K. B., P. Y. Faccioli, M. F. Bonesso, S. Fernandes, A. A. Oliveira, A. Dantas, L. F. Zafalon, and M. L. Cunha. 2017. Characteristics of resistance and virulence factors in different species of coagulase-negative staphylococci isolated from milk of healthy sheep and animals with subclinical mastitis. J. Dairy Sci. 100:2184-2195. https://doi.org/10.3168/jds.2016-11583.

Mørk, T., H. J. Jørgensen, M. Sunde, B. Kvitle, S. Sviland, S. Waage, and T. Tollersrud. 2012. Persistence of staphylococcal species and genotypes in the bovine udder. Vet. Microbiol. 159:171-180. https://doi.org/10.1016/j.vetmic.2012.03.034.

Osterås, O., L. Sølverød, and O. Reksen. 2006. Milk culture results in a large Norwegian survey - Effects of season, parity, days in milk, resistance, and clustering. J. Dairy Sci. 89:1010-1023. https://doi .org/10.3168/jds.S0022-0302(06)72167-1.

Pearson, L. J., J. H. Williamson, S. A. Turner, S. J. Lacy-Hulbert, and J. E. Hillerton. 2013. Peripartum infection with Streptococcus uberis but not coagulase-negative staphylococci reduced milk production in primiparous cows. J. Dairy Sci. 96:158-164. https:// doi.org/10.3168/jds.2012-5508.

Persson, Y., A. K. Nyman, and U. Grönlund-Andersson. 2011. Etiology and antimicrobial susceptibility of udder pathogens from cases of subclinical mastitis in dairy cows in Sweden. Acta Vet. Scand. 53:36. https://doi.org/10.1186/1751-0147-53-36. 
Persson Waller, K., A. Aspán, A. Nyman, Y. Persson, and U. G. Andersson. 2011. CNS species and antimicrobial resistance in clinical and subclinical bovine mastitis. Vet. Microbiol. 152:112-116. https://doi.org/10.1016/j.vetmic.2011.04.006.

Petzer, I. M., J. Karzis, J. C. Watermeyer, T. J. Van der Schans, and R. Van Reenen. 2009. Trends in udder health and emerging mastitogenic pathogens in South African dairy herds. J. S. Afr. Vet. Assoc. 80:17-22.

Piessens, V., E. Van Coillie, B. Verbist, K. Supre, G. Braem, A. Van Nuffel, L. De Vuyst, M. Heyndrickx, and S. De Vliegher. 2011. Distribution of coagulase-negative Staphylococcus species from milk and environment of dairy cows differs between herds. J. Dairy Sci. 94:2933-2944. https://doi.org/10.3168/jds.2010-3956.

Pitkälä, A., M. Haveri, S. Pyörälä, V. Myllys, and T. Honkanen-Buzalski. 2004. Bovine mastitis in Finland 2001-Prevalence, distribution of bacteria, and antimicrobial resistance. J. Dairy Sci. 87:2433-2441. https://doi.org/10.3168/jds.S0022-0302(04)73366 -4 .

Pizauro, L. J. L., C. C. de Almeida, G. A. Soltes, D. Slavic, O. D. Rossi-Junior, F. A. de Ávila, L. F. Zafalon, and J. I. MacInnes. 2017. Species level identification of coagulase negative Staphylococcus spp. from buffalo using matrix-assisted laser desorption ionization-time of flight mass spectrometry and cydB real-time quantitative PCR. Vet. Microbiol. 204:8-14. https://doi.org/10.1016/j .vetmic.2017.03.036.

Raspanti, C. G., C. C. Bonetto, C. Vissio, M. S. Pellegrino, E. B. Reinoso, S. A. Dieser, C. I. Bogni, A. J. Larriestra, and L. M. Odierno. 2016. Prevalence and antibiotic susceptibility of coagulasenegative Staphylococcus species from bovine subclinical mastitis in dairy herds in the central region of Argentina. Rev. Argent. Microbiol. 48:50-56. https://doi.org/10.1016/j.ram.2015.12.001.

Sampimon, O. C., H. W. Barkema, I. M. Berends, J. Sol, and T. J. Lam. 2009. Prevalence and herd-level risk factors for intramammary infection with coagulase-negative staphylococci in Dutch dairy herds. Vet. Microbiol. 134:37-44. https://doi.org/10.1016/j .vetmic.2008.09.010.

Sampimon, O. C., T. J. Lam, D. J. Mevius, Y. H. Schukken, and R. N. Zadoks. 2011. Antimicrobial susceptibility of coagulase-negative staphylococci isolated from bovine milk samples. Vet. Microbiol. 150:173-179. https://doi.org/10.1016/j.vetmic.2011.01.017.

Sawant, A. A., B. E. Gillespie, and S. P. Oliver. 2009. Antimicrobial susceptibility of coagulase-negative Staphylococcus species isolated from bovine milk. Vet. Microbiol. 134:73-81. https://doi.org/10 $.1016 /$ j.vetmic.2008.09.006.

Supré, K., F. Haesebrouck, R. N. Zadoks, M. Vaneechoutte, S. Piepers, and S. De Vliegher. 2011. Some coagulase-negative Staphylococcus species affect udder health more than others. J. Dairy Sci. 94:2329-2340. https://doi.org/10.3168/jds.2010-3741.
Taponen, S., J. Koort, J. Bjorkroth, H. Saloniemi, and S. Pyörälä. 2007. Bovine intramammary infections caused by coagulase-negative staphylococci may persist throughout lactation according to amplified fragment length polymorphism-based analysis. J. Dairy Sci. 90:3301-3307. https://doi.org/10.3168/jds.2006-860.

Taponen, S., S. Nykäsenoja, T. Pohjanvirta, A. Pitkälä, and S. Pyörälä. 2016. Species distribution and in vitro antimicrobial susceptibility of coagulase-negative staphylococci isolated from bovine mastitic milk. Acta Vet. Scand. 58:12. https://doi.org/10.1186/s13028-016 -0193-8.

Taponen, S., H. Simojoki, M. Haveri, H. D. Larsen, and S. Pyörälä 2006. Clinical characteristics and persistence of bovine mastitis caused by different species of coagulase-negative staphylococci identified with API or AFLP. Vet. Microbiol. 115:199-207. https://doi.org/10.1016/j.vetmic.2006.02.001.

Tenhagen, B. A., G. Koster, J. Wallmann, and W. Heuwieser. 2006. Prevalence of mastitis pathogens and their resistance against antimicrobial agents in dairy cows in Brandenburg, Germany. J. Dairy Sci. 89:2542-2551. https://doi.org/10.3168/jds.S0022 $-0302(06) 72330-\mathrm{X}$.

Thorberg, B. M., and B. Brändström. 2000. Evaluation of two commercial systems and a new identification scheme based on solid substrates for identifying coagulase-negative staphylococci from bovine mastitis. J. Vet. Med. B Infect. Dis. Vet. Public Health 47:683-691.

Thorberg, B. M., M. L. Danielsson-Tham, U. Emanuelson, and K. Persson Waller. 2009. Bovine subclinical mastitis caused by different types of coagulase-negative staphylococci. J. Dairy Sci. 92:4962-4970. https://doi.org/10.3168/jds.2009-2184.

Tomazi, T., J. L. Gonçalves, J. R. Barreiro, M. A. Arcari, and M. V. dos Santos. 2015. Bovine subclinical intramammary infection caused by coagulase-negative staphylococci increases somatic cell count but has no effect on milk yield or composition. J. Dairy Sci. 98:3071-3078. https://doi.org/10.3168/jds.2014-8466.

Vanderhaeghen, W., S. Piepers, F. Leroy, E. Van Coillie, F. Haesebrouck, and S. De Vliegher. 2014. Invited review: Effect, persistence, and virulence of coagulase-negative Staphylococcus species associated with ruminant udder health. J. Dairy Sci. 97:5275-5293. https://doi.org/10.3168/jds.2013-7775.

Vanderhaeghen, W., S. Piepers, F. Leroy, E. Van Coillie, F. Haesebrouck, and S. De Vliegher. 2015. Identification, typing, ecology and epidemiology of coagulase negative staphylococci associated with ruminants. Vet. J. 203:44-51. https://doi.org/10.1016/j.tvjl .2014.11.001.

VäxaSverige. 2016. Redogorelse for husdjursorganisationens Djurhalsovard 2014/2015. [Report on animal health care within the livestock organisation 2014/2015]. Växa Sverige, Stockholm, Sweden. 


\section{APPENDIX}

\section{Herd density (\%)}

\begin{tabular}{|l|l|}
\hline & $0-1$ \\
\hline & $2-4$ \\
5 & -6 \\
7 & -10 \\
$11-18$
\end{tabular}

\section{(\%)}

(1)
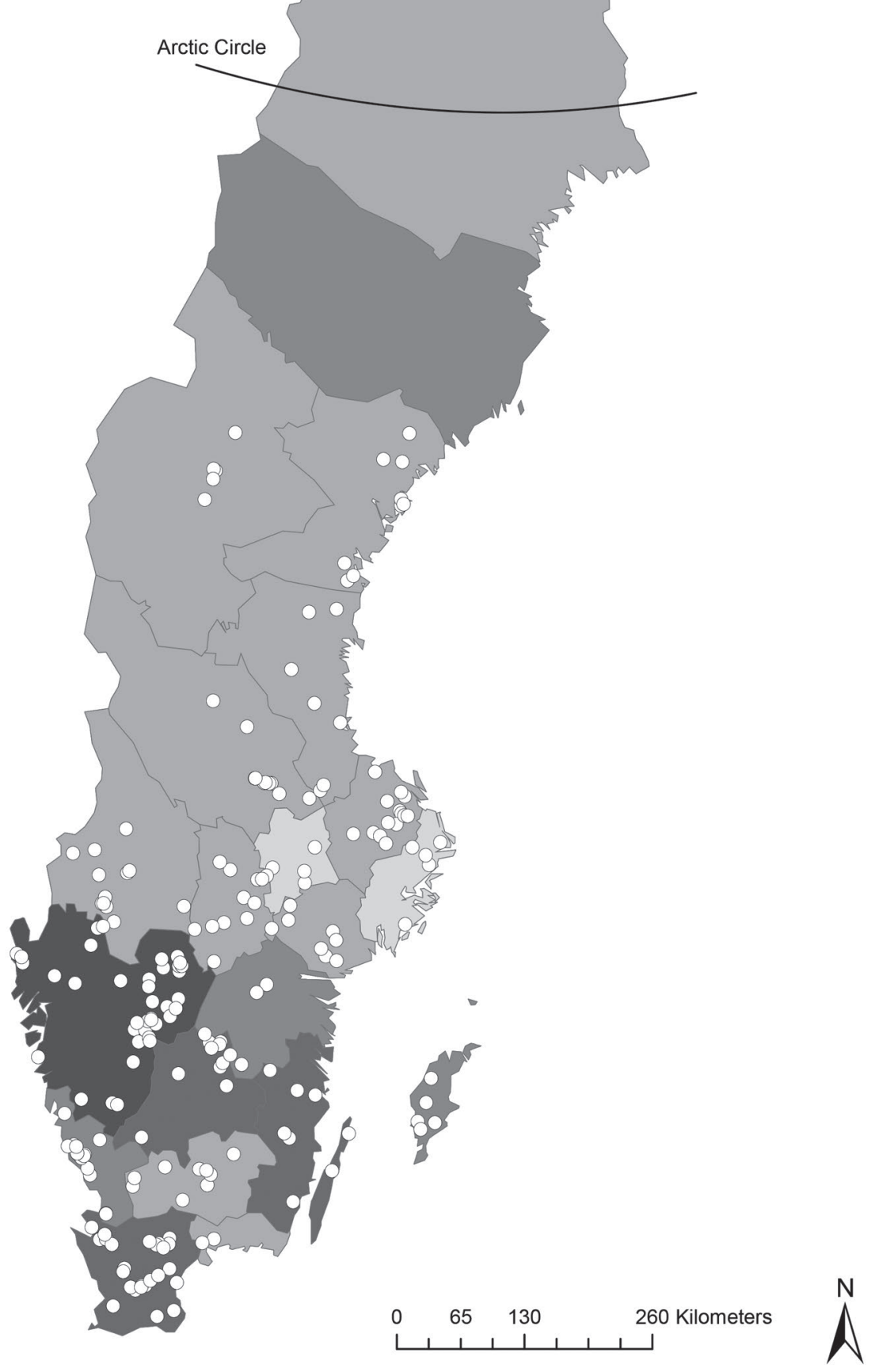

Figure A1. Map of Sweden with dairy herd densities (in \%) per area and the distribution of participating herds (white dots). 
Table A1. Multivariable mixed-effect ordered logistic regression analysis of associations between quarter milk California mastitis test and non-aureus staphylococci (NAS; $\mathrm{n}=639$ )

\begin{tabular}{|c|c|c|c|c|c|}
\hline Variable & $\beta^{1}$ & $\mathrm{SE}$ & $\mathrm{OR}^{2}$ & $95 \%$ CI (OR) & $P$-value \\
\hline Intercept 1 & -3.80 & 0.68 & - & -5.14 to -2.46 & $<0.001$ \\
\hline Intercept 2 & -1.95 & 0.58 & - & -3.08 to -0.82 & 0.001 \\
\hline Intercept 3 & 1.70 & 0.58 & - & 0.56 to 2.84 & 0.004 \\
\hline Intercept 4 & 4.45 & 0.75 & - & 2.97 to 5.92 & $<0.001$ \\
\hline \multicolumn{6}{|l|}{ Interaction: parity $\times$ NAS } \\
\hline \multicolumn{6}{|l|}{ First-parity cows } \\
\hline Staphylococcus epidermidis & Referent & - & - & - & - \\
\hline Staphylococcus simulans & 0.27 & 0.67 & 1.31 & 0.35 to 4.85 & 0.69 \\
\hline Staphylococcus chromogenes & 0.54 & 0.58 & 1.71 & 0.55 to 5.37 & 0.36 \\
\hline Staphylococcus haemolyticus & 0.63 & 0.81 & 1.87 & 0.38 to 9.15 & 0.44 \\
\hline Staphylococcus saprophyticus & 1.03 & 1.36 & 2.80 & 0.19 to 40.5 & 0.45 \\
\hline Staphylococcus xylosus & -1.61 & 1.17 & 0.20 & 0.02 to 1.97 & 0.17 \\
\hline Staphylococcus hyicus & 3.71 & 1.28 & 40.9 & 3.34 to 502.6 & 0.004 \\
\hline \multicolumn{6}{|l|}{ Second-parity cows } \\
\hline S. epidermidis & 2.18 & 0.75 & 8.88 & 2.04 to 38.6 & 0.004 \\
\hline S. simulans & 1.69 & 0.76 & 5.43 & 1.22 to 24.1 & 0.03 \\
\hline S. chromogenes & 0.13 & 0.80 & 1.14 & 0.24 to 5.46 & 0.87 \\
\hline S. haemolyticus & 2.26 & 0.85 & 9.61 & 1.82 to 50.6 & 0.008 \\
\hline S. saprophyticus & 0.37 & 1.56 & 1.46 & 0.07 to 31.2 & 0.81 \\
\hline S. xylosus & 1.52 & 1.38 & 4.56 & 0.31 to 67.6 & 0.27 \\
\hline S. hyicus & -0.29 & 1.57 & 0.75 & 0.03 to 16.1 & 0.85 \\
\hline \multicolumn{6}{|l|}{ Third-parity and greater cows } \\
\hline S. epidermidis & 2.70 & 0.71 & 14.9 & 3.68 to 60.1 & $<0.001$ \\
\hline S. simulans & 1.19 & 0.67 & 3.30 & 0.89 to 12.2 & 0.07 \\
\hline S. chromogenes & 0.52 & 1.05 & 1.68 & 0.22 to 13.1 & 0.62 \\
\hline S. haemolyticus & 1.08 & 0.76 & 2.95 & 0.66 to 13.1 & 0.16 \\
\hline S. saprophyticus & 1.00 & 1.14 & 2.71 & 0.29 to 25.5 & 0.38 \\
\hline S. xylosus & 1.15 & 1.37 & 3.16 & 0.22 to 46.0 & 0.40 \\
\hline S. hyicus & 1.39 & 1.39 & 4.02 & 0.26 to 61.5 & 0.32 \\
\hline
\end{tabular}

${ }^{1} \beta=$ regression coefficients.

${ }^{2} \mathrm{OR}=$ odds ratio. 
NYMAN ET AL.

Table A2. Multivariable mixed-effect linear regression analysis of associations between quarter milk SCC and non-aureus staphylococci (NAS; $\mathrm{n}=237$ )

\begin{tabular}{|c|c|c|c|c|c|}
\hline Variable & $\beta^{1}$ & $\mathrm{SE}$ & $\mathrm{LSM}^{2}$ & $95 \%$ CI (LSM) & $P$-value \\
\hline Intercept & 7.43 & 0.17 & & & $<0.001$ \\
\hline \multicolumn{6}{|l|}{ Interaction: parity $\times$ NAS } \\
\hline \multicolumn{6}{|l|}{ First-parity cows } \\
\hline Staphylococcus epidermidis & Referent & - & 1,694 & $1,203-2,384$ & - \\
\hline Staphylococcus simulans & -0.32 & 0.21 & 1,234 & $960-1,587$ & 0.14 \\
\hline Staphylococcus chromogenes & -0.08 & 0.19 & 1,555 & $1,285-1,882$ & 0.65 \\
\hline Staphylococcus haemolyticus & 0.27 & 0.23 & 2,218 & $1,623-3,032$ & 0.24 \\
\hline Staphylococcus saprophyticus & -0.64 & 0.57 & 895 & $304-2,635$ & 0.26 \\
\hline Staphylococcus xylosus & -0.44 & 0.27 & 1,089 & $715-1,657$ & 0.11 \\
\hline Staphylococcus hyicus & 0.68 & 0.36 & 3,354 & $1,816-6,194$ & 0.055 \\
\hline \multicolumn{6}{|l|}{ Second-parity cows } \\
\hline S. epidermidis & 0.51 & 0.24 & 2,826 & $2,028-3,938$ & 0.03 \\
\hline S. simulans & 0.38 & 0.25 & 2,490 & $1,725-3,595$ & 0.12 \\
\hline S. chromogenes & -0.29 & 0.24 & 1,262 & $911-1,748$ & 0.21 \\
\hline S. haemolyticus & 0.27 & 0.23 & 2,221 & $1,648-2,995$ & 0.23 \\
\hline S. saprophyticus & -0.94 & 0.33 & 660 & $377-1,156$ & 0.005 \\
\hline S. xylosus & -0.80 & 0.43 & 758 & $350-1,638$ & 0.06 \\
\hline S. hyicus & -0.29 & 0.36 & 1,260 & $676-2,347$ & 0.41 \\
\hline \multicolumn{6}{|l|}{ Third-parity and greater cows } \\
\hline S. epidermidis & 0.44 & 0.20 & 2,643 & $2,127-3,284$ & 0.02 \\
\hline S. simulans & 0.24 & 0.21 & 2,148 & $1,705-2,705$ & 0.25 \\
\hline S. chromogenes & 0.14 & 0.28 & 1,954 & $1,256-3,040$ & 0.61 \\
\hline S. haemolyticus & 0.08 & 0.23 & 1,843 & $1,357-2,503$ & 0.71 \\
\hline S. saprophyticus & -0.34 & 0.27 & 1,208 & $795-1,837$ & 0.22 \\
\hline S. xylosus & -0.50 & 0.30 & 1,023 & $630-1,662$ & 0.09 \\
\hline S. hyicus & 0.17 & 0.37 & 2,000 & $1,050-3,811$ & 0.65 \\
\hline
\end{tabular}

${ }^{1} \beta=$ regression coefficients.

${ }^{2}$ Least squares means on cow composite SCC transformed using the natural logarithm scale back-transformed to original scale $(\times 1,000$ cells $/ \mathrm{mL})$. 